Año LI. urtea

$127-2019$

Urtarrila-ekaina

Enero-junio

5

รar.

ats

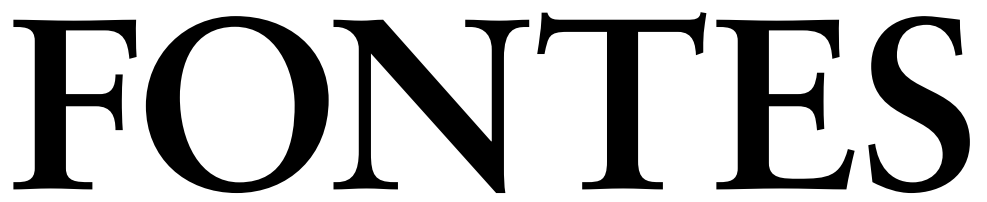

LINGVÆ

VASCONVM

STVDIA ET DOCVMENTA

SEPARATA

Changes in the pitch-accent system of Gernika Basque

Itxaso RODRÍGUEZ-ORDÓÑEZ

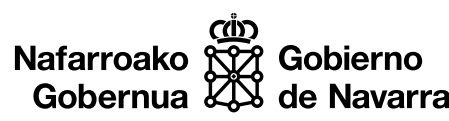

0000 


\title{
Changes in the pitch-accent system of Gernika Basque
}

\author{
Gernikako doinu-azentu sisteman zenbait aldaketa
}

Cambios en el acento vasco del habla de Gernika

Itxaso RODRÍGUEZ-ORDÓÑEZ

Southern Illinois University Carbondale

itxaso.rodriguez-ordonez@siu.edu

I would like to thank the speakers of Gernika Basque for taking the time to participate in this study. The author also thanks Ekaitz Santazilia and two anonymous reviewers for their helpful comments and suggestions on earlier versions of the manuscript. 


\begin{abstract}
The pitch-accent system in Northern Bizkaian Basque (NBB) is characterized for making a pitch distinction between lexical accented/unaccented words (i.e. singular vs. plural contrast) and for lacking a durational correlate of accentual prominence. The present study examines whether such system is maintained in Gernika Basque, a variety of NBB. Results show that younger speakers (ages 18-45) from Spanish speaking households are more likely to show no pitch differences to convey a singular/plural contrast if they also belong to Spanish-speaking social networks. Although duration correlates were found among some speakers, its use was not directly related to the loss of contrast in pitch.
\end{abstract}

Keywords: Basque accent; language change; Gernika Basque.

\title{
LABURPENA
}

Bizkaiko Iparraldeko doinu-azentu sistemak hitz azentudunak edo azentugabeak ezberdintzen ditu (adibidez, singularra eta pluralen artean), baina iraupenak ez du azentuarekiko garrantzirik. Lan honetan, Gernikako doinu-azentu sistema gazteen artean mantentzen den aztertzea dugu helburu. Emaitzek erakusten dute gazteek (18-45 urte bitartekoak) singularra eta pluralaren arteko ezberdintasuna ez dutela mantentzen guraso elebidunak edo erdaldun elebakarrak badituzte, baina baldin eta sare sozial erdaldunak badituzte ere. Nahiz eta hiztun batzuek iraupena erabiltzen duten silaba azentudunak markatzeko, iraupenak duen garrantzia ez du zerikusi handirik hiztunek tonu diferentziarekiko duten galera aldetik.

Gako hitzak: euskal azentua; hizkuntz aldakortasuna; Gernikako hizkera.

\section{RESUMEN}

El sistema acentual del norte de Vizcaya emplea el tono para distinguir palabras lexicales acentuadas y no acentuadas (singular y plural), mientras que la duración no es un correlato acentual. En este trabajo analizamos si dicho sistema se mantiene en el habla de Gernika, una variedad del norte de Vizcaya. Los resultados indican que los hablantes jóvenes (18-45 años de edad) que provienen de casas castellano-parlantes tienden a no mostrar una diferencia tonal, siempre y que éstos también se socialicen en redes sociales de habla castellana. Aunque algunos hablantes emplean la duración como correlato acentual, esto no indica que sea consecuencia de la pérdida del contraste tonal.

Palabras clave: acento; cambio lingüístico; el habla de Gernika. 
1. Introduction. 2. The Prosodic SySTEM OF Gernika BASQUe. 2.1. Distinction between accented and unaccented words. 2.2. Duration. 3. THE STUDY. 3.1. Participants. 3.2. Materials. 3.3. Procedures. 3.4. Analysis. 3.4.1. Downstep. 3.4.2. Duration. 4. RESULTS. 4.1. Downstep. 4.2. Duration. 4.3. Individual analysis. 5. DISCUSSION AND CONCLUSIONS. 6. REFERENCES. 7. APPENDIX.

\section{INTRODUCTION}

Beckman's (1986) typological description of accentual systems classifies languages as either stress-accented or non-stress-accented (i.e. pitch-accent or tonal accent systems). Stress-accent languages like Spanish use a combination of pitch, duration and intensity to convey accentual prominence, whereas pitch-accent languages only use pitch, lacking a duration correlate of accentual prominence. Northern Bizkaia Basque (NBB, henceforth) has been traditionally characterized as a pitch-accented system, sharing four prototypical characteristics with Tokyo Japanese (Hualde, 1988, 1991; Hualde, Elordieta, Gaminde \& Smiljanic, 2002): (i) lexical accented/unaccented (A/U) distinction, (ii) invariable realization of accents as $\mathrm{H}^{*} \mathrm{~L}$, (iii) initial rise (\%LH-), and (iv) no durational correlates of accentual prominence. Most work on dialects that conform to the NBB systems have shown that these varieties fall under pitch-accentual systems that lack durational correlates (Hualde, Smiljanic \& Cole, 2000; Elordieta \& Hualde, 2001, 2003). However, sociolinguistic work on other traditionally known pitch-accents varieties (Errenteria Basque) have shown a pattern that corresponds to that of a stress-accent system (Irurtzun, 2003). In the same vein, Elordieta \& Hualde (2014) argue that, in the presence of stable bilingualism with either Spanish or French, "the present trend [...] is dephonologization of lexical prosodic contrast and the adoption of utterance-level prosody in favor of the dominant language" (p. 207).

More recently, Rodríguez-Ordóñez \& Gillig (2018) tested the lexical accented/unaccented $(\mathrm{A} / \mathrm{U})$ distinction in the production of declarative sentences in Gernika Basque, a dialect that falls under NBB. The authors found that the $\mathrm{A} / \mathrm{U}$ distinction was being lost among some Spanish-dominant speakers. The extent to which speakers may be losing the $\mathrm{A} / \mathrm{U}$ distinction or may convey accentual prominence through other cues (i.e. 
duration) in Gernika Basque is still a matter of research. Therefore, the main goal of the present study is to contribute to a larger body of research on the potential changes of the Basque accentual systems from an apparent-time construct (Chambers, 2004, p. 355-364). In doing so, we examine whether the pitch-accent system of Gernika Basque is adopting a more stress-like pattern due to contact with Spanish. Particularly, we are interested in examining the extent to which the A/U distinction is being lost in Gernika Basque and whether its loss is compensated with durational correlates, as in Spanish.

\section{THE PROSODIC SYSTEM OF GERNIKA BASQUE}

The present study examines two properties of the accentual system of Gernika Basque (GB), a variety that falls under Northern Bizkaian Basque (NBB): 1) the distinction between lexically accented and unaccented words, and 2) lack of duration correlates of accentual prominence. In the present section, we provide a description of the NBB system and recent findings on the GB variety.

\subsection{Distinction between accented and unaccented words}

Northern Bizkaian Basque is known for marking a distinction between lexically accented and unaccented words, similar to Tokyo Japanese (Hualde, 1988, 1991; Kubozono, 1993; Pierrehumbert \& Beckman, 1988). Words that belong to the lexically unaccented class (most nouns and adjectives) are assigned an accent in their last syllable when pronounced in isolation or immediately preceding a non-focalized verb (1a) (Hualde, 1988, 1991, 2002, 2006; Elordieta, 1997, 1998; Gaminde, 1993, 1998). Jun \& Elordieta (1997) have called this accent derived accent as way to distinguish it from the lexical accent that accented words bear (we use the grave accent mark (') for derived accent and the acute accent mark (') for lexical accent). Although first accounts on this derived accent were proposed for a nearby dialect (Lekeitio Basque, also NBB; Elordieta $(1997,1998,2003))$, this aspect is shared by all NBB local varieties (Elordieta \& Hualde, 2014). Additionally, there are a number of accented suffixes such as absolutive plural $-(e) k$, plural genitive $-(e) n$ or locative $-t i k$, that when added to unaccented roots, an accentual prominence is assigned to the root (1b). Local varieties within NBB exhibit some variation as to which syllable bears the accent. In Gernika Basque, accentual prominence is assigned to the syllable immediately preceding the first accented suffix.

(la) Unaccented class

lagunè 'friend' (absolutive singular)

abadiè 'priest' (absolutive singular) (1b) Accented class

lagúnek 'friends' (absolutive plural) lagúnen 'of the friends' (genitive plural) abadíek 'priests' (absolutive plural) abadien 'of the priests' (genitive plural)

It bears to note however, that if an accented morpheme is added to an already lexically accented root, the accented suffix has no bearing on the accented root, that is, the accented syllable remains the same. This can be seen in the accented word amuma 'grandmother' in $(2 \mathrm{a})$ : 


\section{(2a) Accented class \\ amúma 'grandmother' (absolutive singular) \\ amúmak 'grandmothers' (absolutive plural) \\ amúman 'of the grandmother(s)' (genitive singular/plural)}

With respect to sentence-level prosody, declarative utterances in NBB are organized in three prosodic structures: a) Accentual Phrases (APs), Intermediate Phrases (IPS) and Intonational Phrases (IPs) (Elordieta, 1997, 1998; Jun \& Elordieta, 1997; Hualde et al., 2002; Elordieta \& Hualde, 2014) ${ }^{1}$. In the present study, we are only interested in the smallest prosodic structure, namely Accentual Phrases (AP)s, whose schematic structure is realized as in (3):

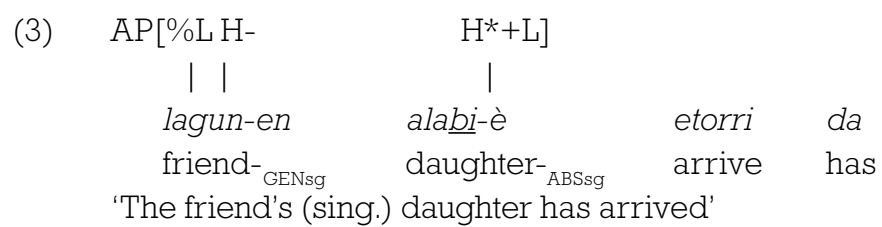

APs in NBB consist of an initial low boundary tone $(\% \mathrm{~L})$ followed by rise on the second syllable that leads to a phrasal $\mathrm{H}$ tone $(\mathrm{H}-)$ and a $\mathrm{H}^{*}+\mathrm{L}$ pitch accent. For sentences containing two unaccented words as in (3), the phrasal high tone on the second syllable spreads until the accented syllable, creating a plateau. Jun \& Elordieta (1997) found that in APs that contain 4 syllables, the peak of $\mathrm{H}$ - is reached on the second syllable, but in APs with more than 4 syllables the peak of $\mathrm{H}$ - is reached on the third syllable. Moreover, when the second syllable is associated with a pitch accent (such as lagunen 'of the friends' (pl)), the high plateau (H-) is not phonetically realized. Instead, if the second syllable is associated with an accent, it will surface with prominence by means of a pitch-accent $\left(\mathrm{H}^{*} \mathrm{~L}\right)$, triggering downstep of a following accent (Hualde et al., 2002; Elordieta \& Hualde, 2014). Thus, the schematic structure of these contours is realized as in (4):

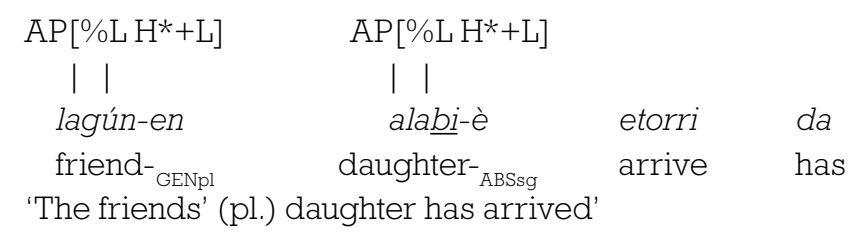

Figures 1 and 2 illustrate the pitch-contours from (3) and (4), respectively. Figure 1 is an example of a sentence containing an unaccented word (lagunen 'of the friend' (sg)) and a word with derived accent (alabiè 'daughter') due to its preverbal position. Figure

1 Elordieta (2015) revises the prosodic structure of NBB and assumes only phonological phrases rather than APs and ips. He assumes a recursive prosodic structure (Ito \& Mester, 2013) with minimal and non-minimal phonological phrases. Elordieta's (2015) new account on the recursive nature of phonological phrases offers an advantage for upstep, but it remains the same as to downstep, which is the focus of this paper. 
2 is an example of a sentence containing an accented word (lagúnen 'of the friends' (pl)) and a word with derived accent (alabiè 'daughter'). Notice that figure 2 shows two $\mathrm{H}^{*}+\mathrm{L}$ pitch accents, in which the second one appears downstepped with respect to the first one.

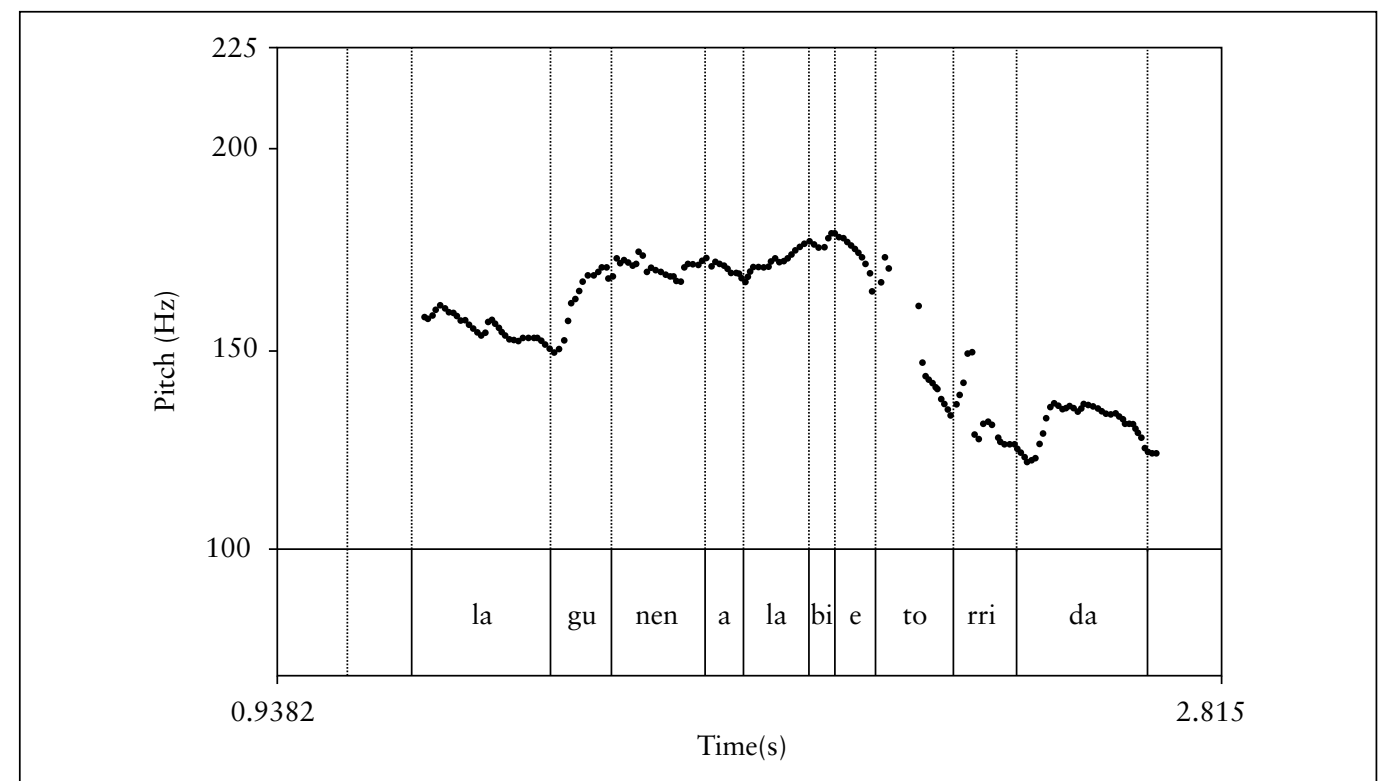

Figure 1. Contour of neutral declarative: unaccented + unaccented (with derived accent). (lagunen alabiè etorri da 'the friend's (sg) daughter has arrived').

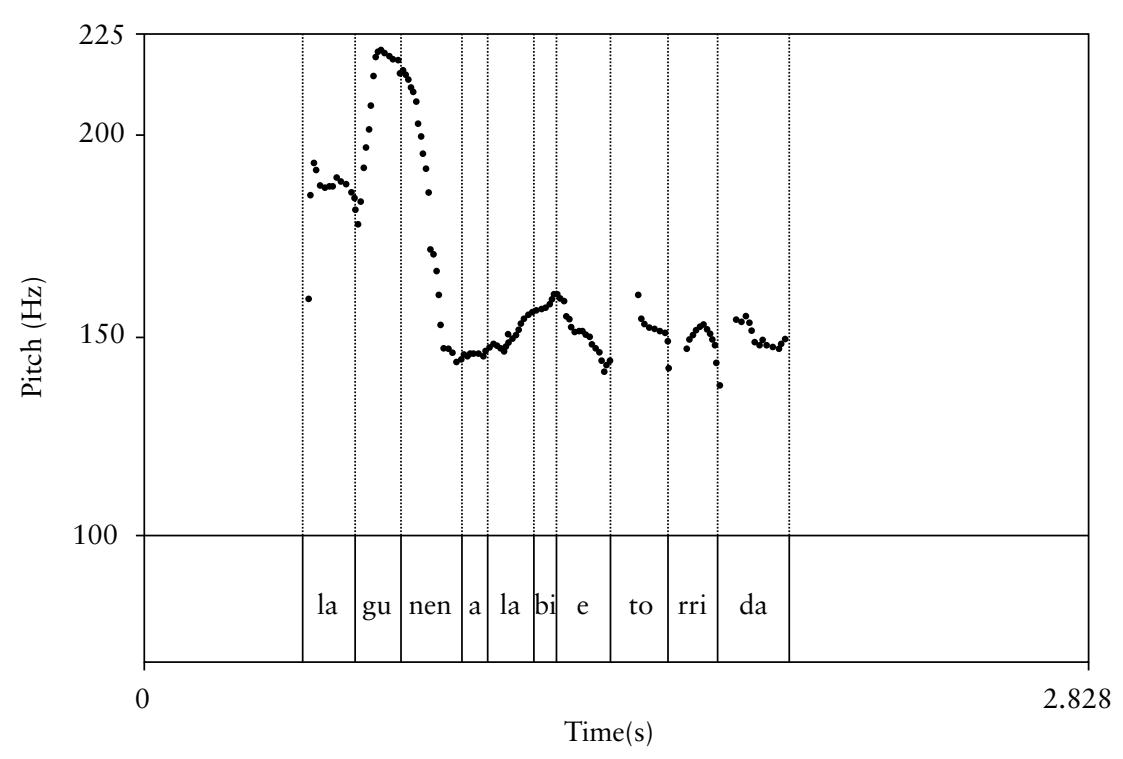

Figure 2. Contour of neutral declarative: accented + unaccented (with derived accent). (lagúnen alabiè etorri da 'the friends' (pl) daughter has arrived'). 


\subsection{Duration}

Previous typological work has suggested that certain pitch-accent systems (i.e. Tokyo Japanese) do not have durational correlates of accentual prominence, that is, syllables bearing accent do not show longer durational patterns (Beckman, 1986; Beckman \& Pierrehumbert, 1986). Similar results have been found for certain dialects conforming the Northern Bizkaian Basque pitch-accent system. For instance, Hualde and colleagues (2000) experimentally tested downstep and duration correlates of accentual prominence in two speakers of NBB, one from Bermeo and one Markina and found that the Bermeo speaker did not exhibit any durational correlates of accentual syllables. Although the Markina speaker showed significantly longer duration in accented syllables than non-accented syllables, it was concluded that such difference $(\sim 5 \mathrm{~ms})$ was too small for it to be perceptually salient, arguing that duration has no bearing as an accentual correlate in these speakers. Similarly, Elordieta \& Hualde $(2001,2003)$ examined duration correlates of accentual prominence in another NBB variety, namely Lekeitio Basque, and found that out of 5 speakers, only 2 showed some durational effects ${ }^{2}$, leading them to the conclusion that pitch (rather than duration) is a much more robust correlate of accentual prominence in this variety. To our knowledge, there is no previous work that has examined duration correlates of accentual prominence in Gernika Basque. Given its typological proximity to the pitch-accent systems of Bemeo, Markina and Lekeitio Basque, one may reasonably ascertain that duration will not constitute a cue for prominence in Gernika Basque, at least among speakers who maintain the accented vs. unaccented distinction through pitch.

Nonetheless, previous work has shown that certain dialects that were historically described as bearing a pitch-accent system, are nowadays patterning more similar to a stress-accent system. For instance, Irurtzun (2003) examined accent placement in Errenteria Basque, a variety in which all words bear an accent. His results showed that although there is a distinction between unmarked words (accent in the second syllable) and marked words (accent in the first syllable), the accentual placement is rapidly disappearing in favor of the unmarked words. The author uses Hualde's (2003) hypothesis to account for such changes, one that states that the pitch-accent system of NBB is the most conservative one. With this in mind, Irurtzun (2003) further hypothesize that the post-initial accent system in central Gipuzkoa developed as the reinterpretation of phrase-initial rises as indicative of the position of the accent, which was possibly triggered directly or indirectly, through contact with Spanish.

Similarly, Elordieta \& Hualde's (2014, p. 407) state that "the present trend in the younger generations is toward [...] dephonologization of lexical prosodic contrast and the adoption of utterance-level prosody that is largely compatible with that of

2 Elordieta \& Hualde (2001) experimentally tested the duration correlates of 6 Lekeitio Basque speakers in two linguistic contexts: a) neutral declarative sentences and b) "narrow contradictory focus". In neutral declarative sentences 3 speakers showed longer durations in the accented syllables and average duration differences between accented and unaccented syllables in these three speakers was very low ( 1ms, $\sim 6 \mathrm{~ms}$, and $\sim 3 \mathrm{~ms})$ and non-significant. In the narrow contradictory focus context, 3 speakers showed higher durations, but such difference was only statistically significant for 1 speaker. 
the majority language", which is confirmed in Irurtzun just cited. Additional corroboration is found in Rodríguez-Ordóñez \& Gillig (2018) who experimentally examined the production of 53 speakers in Gernika Basque. The goal was to determine whether speakers of this $\mathrm{NBB}$ variety maintain the accented vs. unaccented distinction $(\mathrm{A} / \mathrm{U})$ at the utterance level and whether language contact played in role in the potential loss of such distinction. In this study, they examined two types of contrastive minimal pairs: 1) the singular/plural distinction through pitch (lagunen alabiè 'the friend's daughter' vs. lagunen alabiè 'the friends' daughter') 2) pitch differences in contrasting minimal pairs in lexical items (fruteruè 'fruit-seller' vs. frutéroa 'fruit-bowl'). Results show that speakers with more intense contact with Spanish are less likely to maintain the A/U distinction. Additionally, it has been found that the loss in accentual difference was more likely to occur in minimal pairs of the second type (lexical).

An extension from Rodríguez-Ordóñez \& Gillig's (2018) study is to determine whether Gernika Basque speakers, especially those who do not maintain the A/U distinction, resort to duration as an acoustic cue of accentual prominence due to its contact with Spanish. In Spanish, pitch is used as a primary cue of stress, whose basic domain is the word. All Spanish words (except certain monosyllabic words, prepositions and light pronouns) must have one stressed syllable and it is confined to the final three syllables of a word. In declarative sentences, these stressed syllables function as anchoring points for intonational events (Hualde, 2005), and duration works as a secondary acoustic correlate of stress. In this respect, duration is shown to be one of the most important acoustic correlates of accentual prominence in Spanish, in which stressed syllables show higher duration than non-stressed syllables (Navarro-Tomás, 1914, 1964; Quilis, 1971, 1981; Ortega-Llebaria, 2006; Ortega-Llebaria \& Prieto, 2010).

In essence, the present study aims to determine whether the traditional pitch-accent system in Gernika Basque is adopting a more stress-like pattern. In doing so, we build upon the analysis of the A/U distinction in Rodríguez-Ordóñez \& Gillig (2018) and provide a comparative analysis on the acoustic correlates of duration. In particular, we are interested in whether Gernika Basque speakers use duration correlates of accentual prominence, especially among those who do not maintain the A/U distinction. Based on previous work on neighboring dialects of the NBB pitch-accent system, and our knowledge of Spanish prosody, we would expect that those speakers who maintain the $\mathrm{A} / \mathrm{U}$ distinction will not show acoustic correlates of duration, consistent with typological accounts of pitch-accent systems (Beckman, 1986). On the contrary, for the speakers that lack an $\mathrm{A} / \mathrm{U}$ distinction, we would expect duration to be a prosodic cue to convey prosodic prominence. Additionally, if contact with Spanish plays a role, we expect those speakers with more contact with Spanish to show no A/U differences and a durational correlate of prominence.

3 Historically, morpheme -eru was used for professions in contrast with accented -ero. However, it is common to find unaccented -ero as in fruteroà ('fruit-seller') today, especially among the younger generations. 


\section{THE STUDY}

\subsection{Participants}

Out of the 53 speakers examined in Rodríguez-Ordóñez \& Gilig (2018), 45 speakers were selected in this study ${ }^{4}$.

In this study, it was found that the older speakers are quite robust in their distinction between accented and unaccented words. For younger speakers, the only two factors that accounted for the variation in the realization of pitch were SOCIAL NETWORKS and BILINGUAL GROUP, whereas GENDER had no bearing in such variation. Given these results, this study will focus the following three relevant social factors: AGE, BILINGUAL GROUP and SOCIAL NETWORKS.

In the current study, speakers were stratified in two AGE groups: the older group constitutes our control group and it is composed by speakers $(\mathrm{N}=15)$ ages $45-65$, whereas the younger was comprised by those aged 18-35 ( $\mathrm{N}=30)$. In terms of BILINGUAL GROUP, speakers were stratified in three groups: GROUP 1 is composed by speakers with Gernika Basque speaking parents; GROUP 2 encompasses speakers with only one parent that is a Gernika Basque speaker (and the other is a Spanish speaker) whereas GROUP 3 is made up by speakers whose parents are Spanish monolinguals. For each bilingual group, equal number of speakers were considered with respect to SOCIAL NETWORKS, which were measured through a language background questionnaire. In this questionnaire, participants reported their use of Gernika Basque, Standard Basque and Spanish on a Likert scale 1-5 on a number of social domains (parents, school, friends, etc.). The factor of SOCIAL NETWORKS was measured on their self-reported use of language with friends (1=always Spanish; 5=always Gernika Basque $)^{5}$. Based on their reported scale, participants were stratified to belong to Basque-speaking networks if the marked 4 or 5 on the scale or Spanish-speaking networks if they scored 1 or 2 on the scale ${ }^{6}$. Table 1 shows the distribution of the speakers according to these social factors.

Table 1. Number of participants in each group

\begin{tabular}{|l|cc|cc|cc|c|}
\hline & \multicolumn{2}{c|}{ Group 1 } & \multicolumn{2}{c|}{ Group 2 } & \multicolumn{2}{c|}{ Group 3 } & Total \\
\hline Social networks & Basque & Spanish & Basque & Spanish & Basque & Spanish & \\
\hline Older (45-65) & 3 & 2 & 2 & 2 & 3 & 3 & 15 \\
\hline Younger (18-35) & 5 & 5 & 5 & 5 & 5 & 5 & 30 \\
\hline
\end{tabular}

4 This selection was based to keep the number of participants for each social factor as controlled as possible.

5 Participants reported to either speak Gernika Basque, Spanish or both with friends, but nobody reported to speak Standard Basque to their immediate friends.

6 Speakers who scored a 3 on the use of Basque with friends were excluded from analysis. 


\subsection{Materials}

For this study, 4 contrasting minimal pairs ( 8 sentences per speaker) formed by singular genitive and plural genitive -en were used. All sentences were taken from Hualde et al. (2002) and were used in Rodríguez-Ordóñez \& Gillig (2018), and consisted of two lexical words plus a lexical verb and an auxiliary verb. There were two conditions. In condition A, the first word was unaccented and the second word contained a derived accent. We will refer to this condition as the unaccented/accented condition (U/A). In condition $\mathrm{B}$, the first word was accented and the second word was either accented or had a derived accent. We will call this the accented/accented condition (A/A). (5a) and (5b) show these conditions respectively, with the remaining of the test instruments in the appendix.

(5a) Condition A: Unaccented + derived accent (U/A)

$\begin{array}{llll}\text { lagunen } & \text { alabiè } & \text { etorri } & \text { da } \\ \text { Wl } & \text { W2 } & \mathrm{V} & \text { AUX } \\ \text { friend-GENsg } & \text { daughter } & \text { come } & \text { has } \\ \text { 'The friend's daughter has arrived' } & \end{array}$

(5b) Condition B: Accented + derived accent (A/A)

$\begin{array}{lccl}\text { lagúnen } & \text { alabiè } & \text { etorri } & \text { da } \\ \text { Wl } & \text { W2 } & \mathrm{V} & \text { AUX } \\ \text { friend-GENpl } & \text { daughter } & \text { come } & \text { has } \\ \text { 'The friends' daughter has arrived' } & \end{array}$

\subsection{Procedures}

Participants were randomly presented with a Spanish translation of the target sentence in a Powerpoint presentation (1 sentence per slide) and were asked to translate those sentences "into their Basque". Each subject met individually with the author, a native of Gernika, and were recorded in a quiet room in their homes, using a AKG C520 head-mounted condenser microphone and H4N Handheld 4-trk 24-Bit Recorder (with a sampling rate of $44,100 \mathrm{~Hz}$ ). Participants were instructed to repeat the experiment 3 times, that is, they first went over the randomized 8 sentences and were allowed to take a small break between the second and third testing.

\subsection{Analysis}

In order to examine whether Gernika Basque speakers maintain (or have lost) the $\mathrm{A} / \mathrm{U}$ distinction, and whether they use durational correlates of accentual prominence, two measurements were taken: F0 and duration of accented syllables.

\subsubsection{Downstep}

Following previous work on NBB, we assume that downstep is a reliable clue of A/U distinction in Gernika Basque (Hualde et al., 2002, p. 554). It has been previously shown that downstep in $\mathrm{W}_{2}$ consistently indicates the presence of an accent in $\mathrm{W}_{1}$ 
(Hualde et al., 2002) when both words are accented (Condition B). In condition A, however, the first word is unaccented. This condition does not include any preceding pitch-accent and therefore, does not trigger a downstep of the accent on the second word. Importantly, previous work has shown that the first accented peak in condition $\mathrm{B}$ shows higher $\mathrm{F} 0$ values than in condition $\mathrm{A}$, allowing for a downstep environment of the second accented peak (Hualde et al., 2000, 2002). In short, downstep is manifested in the accented syllable for word 2 in condition B but not for condition A.

Using Praat (Boersma \& Weenink, 2018), F0 values for the highest points in word 1 and word 2 were manually extracted from each condition, using the maximum F0 value for the relevant syllable (second). If we were to find a downstep effect, speakers will produce lower F0 values for the accented syllable in word 2 for condition B than in condition A. Lack of such downstep effect will involve similar values of F0 (in $\mathrm{Hz}$ ) for $\mathrm{W}_{1}$ in $\mathrm{W}_{2}$.

\subsubsection{Duration}

With respect to duration, the syllables bearing the first accent in condition B were measured (in ms) and compared to the identical syllable in condition A. These are shown in (6a) and (6b), respectively. The syllables of interest are identical in nature, expect that in condition $\mathrm{A}$, the syllable is not accented whereas in condition $\mathrm{B}$, the syllable is accented. If duration is an acoustic correlate of accentual prominence, we would expect the duration of the accented syllables to be longer.

(6a) Condition A

Lagunen alabiè etorri da

"The daughter of the friend

has arrived' (6b)

\section{Condition B \\ Lagúnen alabiè etorri da \\ 'The daughter of the friends \\ has arrived'}

For the data analysis, we only considered repetition 2 in order to avoid high amounts of degrees of freedom that could potentially create a type I error. Such compromise yielded 360 produced tokens ( 45 speakers $\times 8$ sentences) but a total of 7 tokens had to be excluded due to errors. Some speakers reversed the words for $\mathrm{W}_{1}$ and $\mathrm{W}_{2}$ : instead of producing lagunen amúma etorri da ('the friend's grandmother arrived'), they produced amúman lagunè etorri da ('the grandmother's friend arrived'), reversing thus the accentual conditions. Additionally, some speakers used the Standard Basque word apáiza 'priest' which bears an accent in the second syllable instead of the desired unaccented abadiè 'priest'. Such examples were also excluded, yielding a total of 353 tokens for analysis.

\section{RESULTS}

In what follows with present the data for downstep and duration, respectively. In order to gauge a better understanding of the data, we first report the descriptive statistics, followed by inferential statistics for each measurement. 


\subsection{Downstep}

Table 2 shows the F0 (in $\mathrm{Hz}$ ) mean differences between the highest points of $\mathrm{W}_{1}$ and $\mathrm{W}_{2}$ in both the accented/unaccented $(\mathrm{A} / \mathrm{U})$ and the accented-accented $(\mathrm{A} / \mathrm{A})$ conditions. As shown in table 2 , the difference between the highest points of $\mathrm{W}_{1}$ and $\mathrm{W}_{2}$ are very small for condition $\mathrm{A}$ in all three bilingual groups. The difference between the highest points of $\mathrm{W}_{1}$ and $\mathrm{W}_{2}$ are much larger in condition $\mathrm{B}$. These results are consistent with the presence of downstep in condition $\mathrm{B}$, whereby the presence of an accent in $\mathrm{W}_{1}$ is followed by a lower $\mathrm{F} 0$ in the accented syllable of $\mathrm{W}_{2}$. These results are consistent with previous findings of the presence downstep in other local varieties of NBB in that an accented word triggers downstep of another accented word (as in condition B) but does not when trigger downstep when the preceding word is unaccented (as in condition A) (Elordieta, 1997; Hualde et al., 2000, 2002). These results thus provide preliminary evidence that older speakers maintain a distinction between lexically accented and unaccented words.

Table 2. Means for highest points in $\mathrm{W}_{1}$ and $\mathrm{W}_{2}$ for conditions $\mathrm{A}$ and $\mathrm{B}$ in older speakers

\begin{tabular}{|l|c|c|c|c|} 
Older speakers $^{7}$ & \multicolumn{3}{|c|}{ F0 (Hz) Differences } \\
\cline { 2 - 5 } & \multicolumn{2}{|c|}{$\mathbf{W}_{1}-\mathbf{W}_{2}$} & \multicolumn{2}{c|}{$\mathbf{W}_{1}-\mathbf{W}_{2}$} \\
\cline { 2 - 5 } & Condition A (U/A) & sd & Condition B (A/A) & sd \\
\hline Group 1 & 2,2 & 16,7 & 48,8 & 19,5 \\
\hline Group 2 & 3,2 & 10,6 & 25,7 & 18,1 \\
\hline Group 3 & 0,1 & 9,6 & 34,4 & 27,1 \\
\hline
\end{tabular}

Table 3 and 4 present the descriptive statistics for the three bilingual groups in the younger group for females and males, respectively. Although it has been previously shown that gender is not a relevant social factor in the variation of the maintenance of the A/U distinction in Gernika Basque, we demonstrate the descriptive statistics separated by gender ${ }^{8}$.

7 Recall from section 3.1. that the older group is solely conformed by female speakers.

8 This is because, on average, males are known to have longer vocal tracks as well as longer and thicker vocal folds, which explains their overall lower F0 values (Fant, 1970; Kahane, 1978). 
Table 3. Means for highest points in $\mathrm{W}_{1}$ and $\mathrm{W}_{2}$ for conditions $\mathrm{A}$ and $\mathrm{B}$ in younger female speakers

\begin{tabular}{|l|c|c|c|c|}
\hline \multirow{2}{*}{ Younger females } & \multicolumn{4}{|c|}{ F0 (Hz) Differences } \\
\cline { 2 - 5 } & \multicolumn{2}{|c|}{$\mathbf{W}_{1}-\mathbf{W}_{2}$} & \multicolumn{2}{c|}{$\mathbf{W}_{1}-\mathbf{W}_{2}$} \\
\cline { 2 - 5 } & Condition A (U/A) & sd & Condition B (A/A) & sd \\
\hline Group 1 & $-3,2$ & 9,5 & 35,2 & 16,6 \\
\hline Group 2 & $-2,4$ & 13,8 & 33,3 & 27,2 \\
\hline Group 1 & $-1,1$ & 10,5 & 18,6 & 20,9 \\
\hline
\end{tabular}

Table 4. Means for highest points in $\mathrm{W}_{1}$ and $\mathrm{W}_{2}$ for conditions $\mathrm{A}$ and $\mathrm{B}$ in younger male speakers

\begin{tabular}{|l|c|c|c|c|}
\multirow{2}{*}{ Younger males } & \multicolumn{3}{|c|}{ F0 (Hz) Differences } \\
\cline { 2 - 5 } & \multicolumn{2}{|c|}{$\mathbf{W}_{1}-\mathbf{W}_{2}$} & \multicolumn{2}{c|}{$\mathbf{W}_{1}-\mathbf{W}_{2}$} \\
\cline { 2 - 5 } & Condition A (U/A) & sd & Condition B (A/A) & sd \\
\hline Group 1 & $-4,1$ & 4,4 & 23,9 & 2,8 \\
\hline Group 2 & $-0,1$ & 4,9 & 10,5 & 10,4 \\
\hline Group 3 & 0,5 & 5,8 & 7,3 & 10,6 \\
\hline
\end{tabular}

As it can be seen in tables 3 and 4, the F0 differences between the highest points of words 1 and 2 are higher in condition B than condition A. At first glance, these results may suggest that the presence of an accented word triggers downstep in younger speakers as well. However, one may notice that the average differences between $\mathrm{W}_{1}$ and $\mathrm{W}_{2}$ in condition $\mathrm{B}$ becomes much smaller in different bilingual groups; while speakers in group 1 show relatively larger average differences, such differences become much smaller in groups 2 and 3, especially in males. These results may suggest that males are more likely not to show pitch differences in the $\mathrm{A} / \mathrm{U}$ distinction, but the statistical showed that gender was not a significant factor, as it will be shown later.

In order to determine whether these group differences are statistically significant, we conducted a linear mixed-effects regression analysis using the lmer () function in the lme4 package in $\mathrm{R}$ (Bates et al., 2014). The difference between $\mathrm{W}_{1}$ and $\mathrm{W}_{2}$ was set as the dependent variable after normalizing the F0 values into z-scores with scale under function ave (). We included all 4 fixed factors in the model as interactions (as marked in asterisks *): CONDITION (A vs. B), AGE (older vs. younger) BILINGUAL Group (1, 2 and 3) and Social NeTworks (Basque vs. Spanish). Additionally, we included speaker as a random effect in order to control for intra-speaker variation. The model entered is shown in (7): 
(7) $\quad$ model ${ }^{9}<-\operatorname{lmer}($ Difference_z $\sim$ Condition * Age * Group * Social_Net + (1|speaker), data $=$ Gernika $)^{10}$.

Results from the linear mixed-effects reveal that there was a main effect of CONDITION $(\beta=1.26, t=2.79, \mathrm{p}<0.001)$, suggesting that overall, the $\mathrm{F} 0$ differences between $\mathrm{W}_{1}$ and $\mathrm{W}_{2}$ are indeed larger in condition $\mathrm{B}$ than in condition A. AGE, Group and SocIAL NETWORKS did not show statistically significant differences (all effects at $\mathrm{p}>0.05$ ). However, there was a four-way interaction between CONDITION, Age, Group and SOCIAL _ NETWORKS $(\beta=0.94, t=2.01, \mathrm{p}<0.05)$, suggesting that the distinction between accented and unaccented words is socially conditioned. In order to locate these interactions, a post-hoc analysis was conducted using lsmeans() in $\mathrm{R}$. The post-hoc analysis revealed that all groups showed a statistically significant difference between condition A and B, except for younger speakers in group 3 with Spanish-speaking social networks $(\beta=0.03$, $t=0.31, \mathrm{p}=0.74)$. These results suggest that younger speakers who are born in Spanish-speaking household are more likely to lose the distinction between lexically accented and unaccented words if they also belong to Spanish-speaking networks. These results are visually shown in the boxplots in figure 3 (for younger speakers), with grey boxplots representing F0 differences between the target syllables in $\mathrm{W}_{1}$ and $\mathrm{W}_{2}$ for condition $\mathrm{A}$ and the white boxplots representing the differences for condition $\mathrm{B}$.

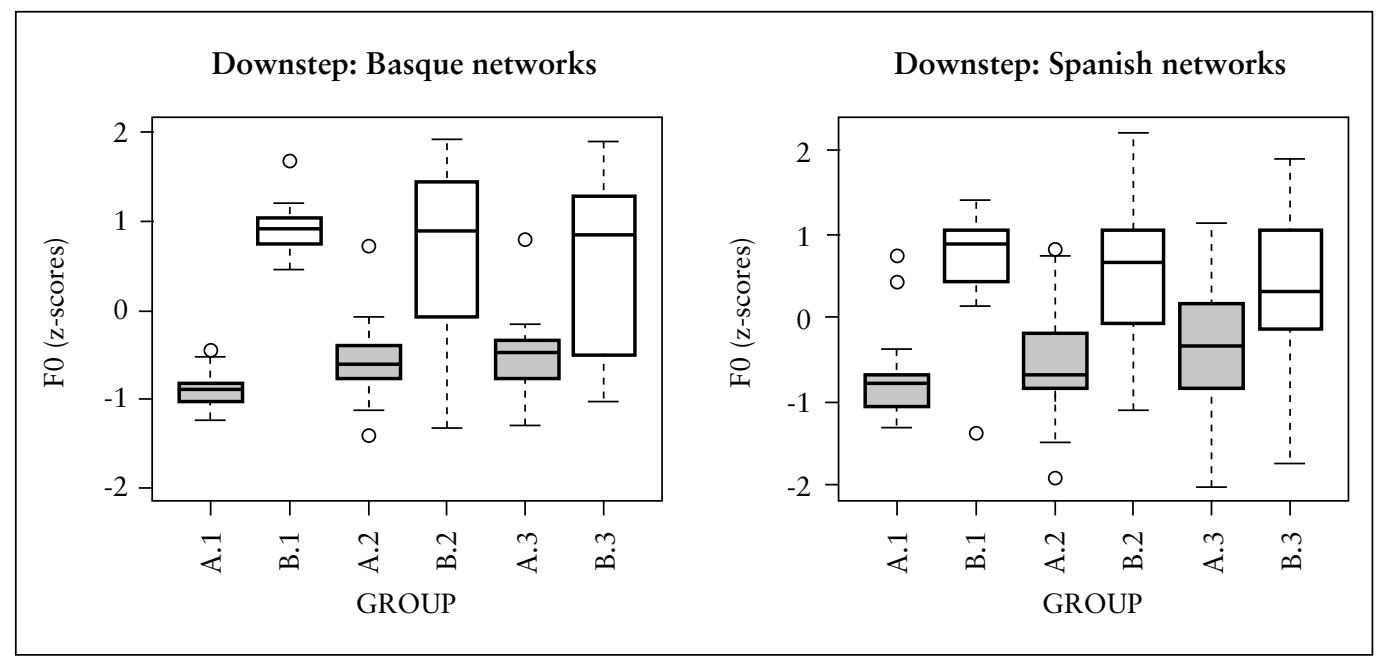

Figure 3. Differences between $\mathrm{W}_{1}$ and $\mathrm{W}_{2}$ (z-scores) in younger speakers. A.1=Group 1, Condition $\mathrm{A}(\mathrm{A} / \mathrm{U})$; B.1=Group 1, Condition B (A/A); A.2=Group 2, Condition A (A/U); B.2=Group 2, Condition B (A/A); A.3=Group 3, Condition A (A/U); B.3=Group 3, Condition B (A/A).

9 We also created a model with GENDER as a fixed factor and did not yield any significant effect. Importantly, the AIC scores were significantly $(\mathrm{p}<0.005)$ higher with Gender than the model without Gender, suggesting that less variation can be accounted for when including Gender in the model. As such, the most optimal model is the one that we present in (7).

10 Difference_z $=$ difference between $\mathrm{W}_{1}$ and $\mathrm{W}_{2}$ normalized F0 into $\mathrm{z}$-scores; Condition = whether the condition contain a pre-accented word (B) or not (A); Age = age group of speakers; Group = the bilingual group speakers belong to; Social_Net = whether speakers belong to Basque or Spanish social networks. 
As it can be seen in figure 3 , the difference between $\mathrm{W}_{1}$ and $\mathrm{W}_{2}$ in condition $\mathrm{B}$ (white boxplots) are consistently higher than for condition A. The differences between conditions A and B become smaller in the bilingual continuum (groups), especially in groups with Spanish social networks (right-most plot). Group 1 shows the widest difference, followed by groups 2 and 3. Despite this pattern, it is important to notice the intra-speaker variation within groups, represented by the longer whiskers, especially in groups 2 and 3. We will discuss individual differences in section 4.3.

In summary, results reveal that older speakers in Gernika Basque show a clear effect of downstep in condition B as opposed to condition A, providing evidence of a distinction between lexically accented and unaccented words. Younger speakers also show evidence of maintaining a pitch distinction between lexically accented and unaccented words but the range of the differences is more variable. The interaction between age, group and social networks reveal that younger speakers are less likely to show a pitch difference between accented and unaccented words if they come from Spanish-speaking households and also belong to Spanish-speaking networks.

\subsection{Duration}

The previous section has examined whether Gernika Basque speakers maintain a distinction between lexically accented and unaccented words through pitch. Our second goal is to determine whether duration is used as an accentual correlate in Gernika Basque. To do so, we measured the duration of the syllables bearing the first accent in condition B (lagúnen 'of the friends' (plural)) and the identical unaccented syllable in condition A (lagunen 'of the friend' (singular)). Previous work has demonstrated that duration is not an acoustic correlate of accentual prominence in NBB (Hualde et al., 2000; Elordieta \& Hualde, 2001, 2003). Here, we test the hypothesis that those who do not show a pitch difference will show a duration difference. As with pitch, we first present the descriptive statistics for duration and then the inferential statistics.

Table 5 shows durations means (in milliseconds) of the accented vs. unaccented syllables for older speakers whereas table 6 shows the duration results for younger speakers.

Table 5. Mean durations (milliseconds) for accented and unaccented syllables in older speakers

\begin{tabular}{|l|c|c|c|c|c|c|}
\hline Older speakers & \multicolumn{2}{|c|}{ lagunen } & \multicolumn{2}{c|}{ lagúnen } & \multicolumn{2}{c|}{ Difference $\boldsymbol{g} \boldsymbol{u}$ vs. $\boldsymbol{g u}$} \\
\hline & $\mathrm{ms}$ & $\mathrm{sd}$ & $\mathrm{ms}$ & $\mathrm{sd}$ & $\mathrm{ms}$ & sd \\
\hline Group 1 & 130,4 & 36,4 & 122,6 & 27,5 & 7,8 & 31,2 \\
\hline Group 2 & 125,8 & 24,5 & 133,7 & 23,1 & $-7,9$ & 23,7 \\
\hline Group 3 & 123,5 & 31,7 & 129,5 & 29,9 & -6 & 30,2 \\
\hline
\end{tabular}


Table 6. Mean durations (milliseconds) for accented and unaccented syllables in young speakers

\begin{tabular}{|l|c|c|c|c|c|c|}
\hline Younger speakers & \multicolumn{2}{|c|}{ lagunen } & \multicolumn{2}{c|}{ lagúnen } & \multicolumn{2}{c|}{ Difference gu vs. $g u ́$} \\
\hline & ms & sd & ms & sd & ms & sd \\
\hline Group 1 & 124 & 42,6 & 126,3 & 36,2 & $-2,3$ & 37,8 \\
\hline Group 2 & 121 & 35,8 & 134,3 & 39,9 & $-13,3$ & 36,2 \\
\hline Group 3 & 104,8 & 27,6 & 122,4 & 32,3 & $-17,6$ & 29,4 \\
\hline
\end{tabular}

When examining the descriptive statistics for the older groups, it is revealed that the accented syllables are slightly longer for groups 2 and 3 in older speakers. Similarly, younger speakers in groups 2 and 3 also show longer durations for accented syllables, but the difference in duration for accented and unaccented syllables is much larger for younger speakers than for older speakers. In order to determine whether these differences are significant, a linear mixed-effects regression analysis was conducted. This model was the same as the one for F0, but with duration (normalized into z-scores) as the dependent variable. As in the previous model, we included CONDITION, AGE, GROUP and SOCIAL NETWORKS as fixed factors and speaker as a random effect.

The model showed that the overall difference in duration between accented and unaccented syllables was not statistically significant $(\beta=0.031, t=0.78, \mathrm{p}=0.56)$. None of the social factors were significant either (all at $\mathrm{p}>0.05$ ). There was a marginally significant interaction between AGE, BILINGUAL GROUP and SOCIAL NETWORKS $(\beta=0.53, t=1.88, \mathrm{p}$ $=0.06)$. The post-hoc analysis shows that the duration differences between accented and unaccented syllables only reached marginally statistical significance in two groups: younger speakers in group 2 with Basque social networks $(\beta=0.52, t=1.79, \mathrm{p}=0.062)$ and younger speakers in group 3 with Spanish social networks $(\beta=0.57, t=1.92, \mathrm{p}=0.054)$.

Figure 4 shows the differences in duration for accented and unaccented syllables in younger speakers, grey boxplots representing the results for unaccented syllables

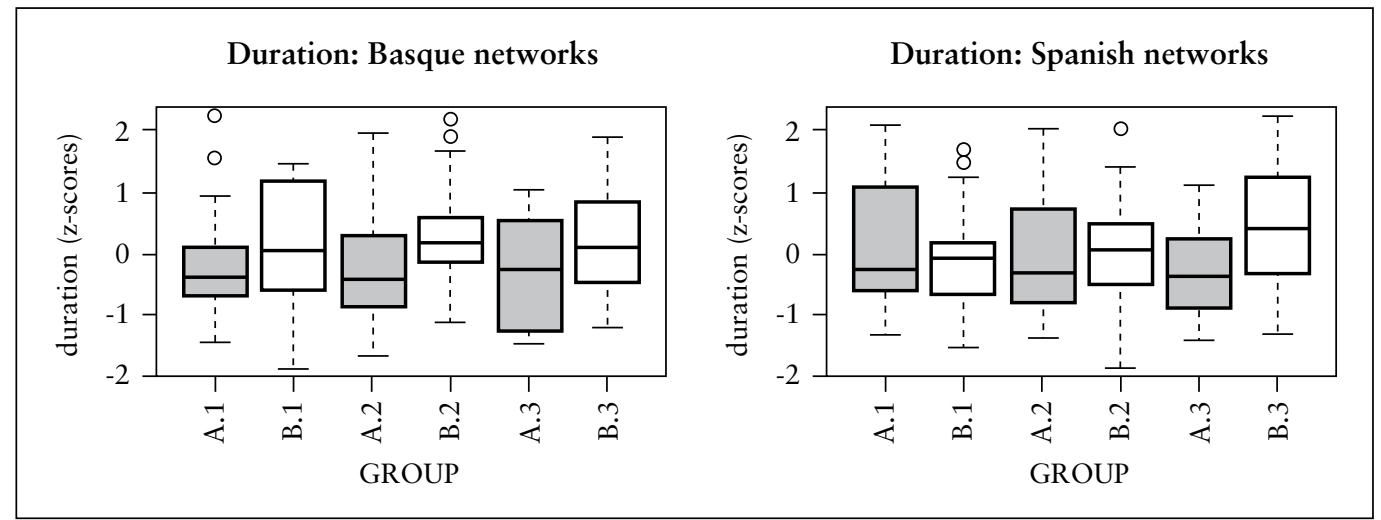

Figure 4. Duration of accented and unaccented syllables (in z-scores) in younger speakers. A.1=Group 1, Condition A (A/U); B.1=Group 1, Condition B (A/A); A.2=Group 2, Condition A (A/U); B.2=Group 2, Condition B (A/A); A.3=Group 3, Condition A (A/U); B.3=Group 3, Condition B (A/A). 
(lagunen 'of the friend' (sg)) and white boxplots representing the results for accented syllables (lagúnen 'of the friends' ( $\mathrm{pl})$ ).

By looking at the boxplots, we see that accented syllables show longer duration than unaccented ones, but such differences were not large enough to reach significance. Based on these results, it is safe to conclude that, overall and at group level, duration does not play a significant role in the accentual prominence of Gernika Basque. An emergent pattern with respect to duration deserves special attention: congruent with the differences found for pitch, the duration of accented syllables increases across the three bilingual groups. In other words, group 1 shows the smallest difference between accented and unaccented syllables, followed by speakers in group 2 and group 3, with this latter group showing the largest difference. Although the effects of these differences were not large enough to render statistical significance at the group level, given the large intra speaker variation, we provide a more nuanced individual analysis to determine a potential relationship between pitch and duration in Gernika Basque.

\subsection{Individual analysis}

A group analysis with respect to the distinction of accented and unaccented words in pitch and duration has demonstrated two things: 1) most Gernika Basque speakers show an accentual difference between lexically accented and unaccented words to express a singular vs. plural distinction, 2) duration does not seem to play a role in marking such distinction. Despite these overall trends, the variation in such accentual difference is socially conditioned: younger speakers that come from Spanish-speaking households that also belong to Spanish-speaking social networks are more likely to lose an accentual distinction (through pitch) between lexically accented and unaccented words. In terms of duration, it was concluded that overall, duration is not an accentual correlate in Gernika Basque. Despite these trends, a noticeable individual variation is revealed, which calls for a more fined-grained analysis with respect to both measurements (downstep and duration) at the individual level.

In examining how Gernika Basque speakers express the singular vs. plural distinction, the following four scenarios could be found:

1) Speakers convey the $\mathrm{sg} / \mathrm{pl}$ contrast solely through pitch: these speakers show downstep in condition B, but not in condition A and show no difference in duration between the accented syllable in lagúnen (pl.) and unaccented syllable in lagunen (sg).

2) Speakers convey the $\mathrm{sg} / \mathrm{pl}$ contrast both through pitch and duration: these speakers show both downstep in condition B, but not in condition $\mathrm{A}$ and show longer duration for the accented syllable in lagúnen (pl.) than in the unaccented syllable lagunen (sg). 
3) Speakers convey the $\mathrm{sg} / \mathrm{pl}$ contrast through duration only: these speakers do not show pitch differences between conditions $\mathrm{A}$ and $\mathrm{B}$ but show longer duration for the accented syllable in lagunen (pl.) than in the unaccented syllable lagunen (sg).

4) Speakers do not convey the sg/pl contrast: These speakers do not show pitch differences between conditions $\mathrm{A}$ and $\mathrm{B}$ and show no difference in duration between the accented syllable in lagúnen (pl.) and unaccented syllable in lagunen (sg).

In order to determine how many speakers conform to one of these scenarios, a number of separate analysis of variance (ANOVA, one per speaker) were conducted on pitch differences between conditions $\mathrm{A}$ and $\mathrm{B}$ and duration differences between accented and unaccented syllables. Figures 5 and 6 show the number of speakers that conform to each category above.

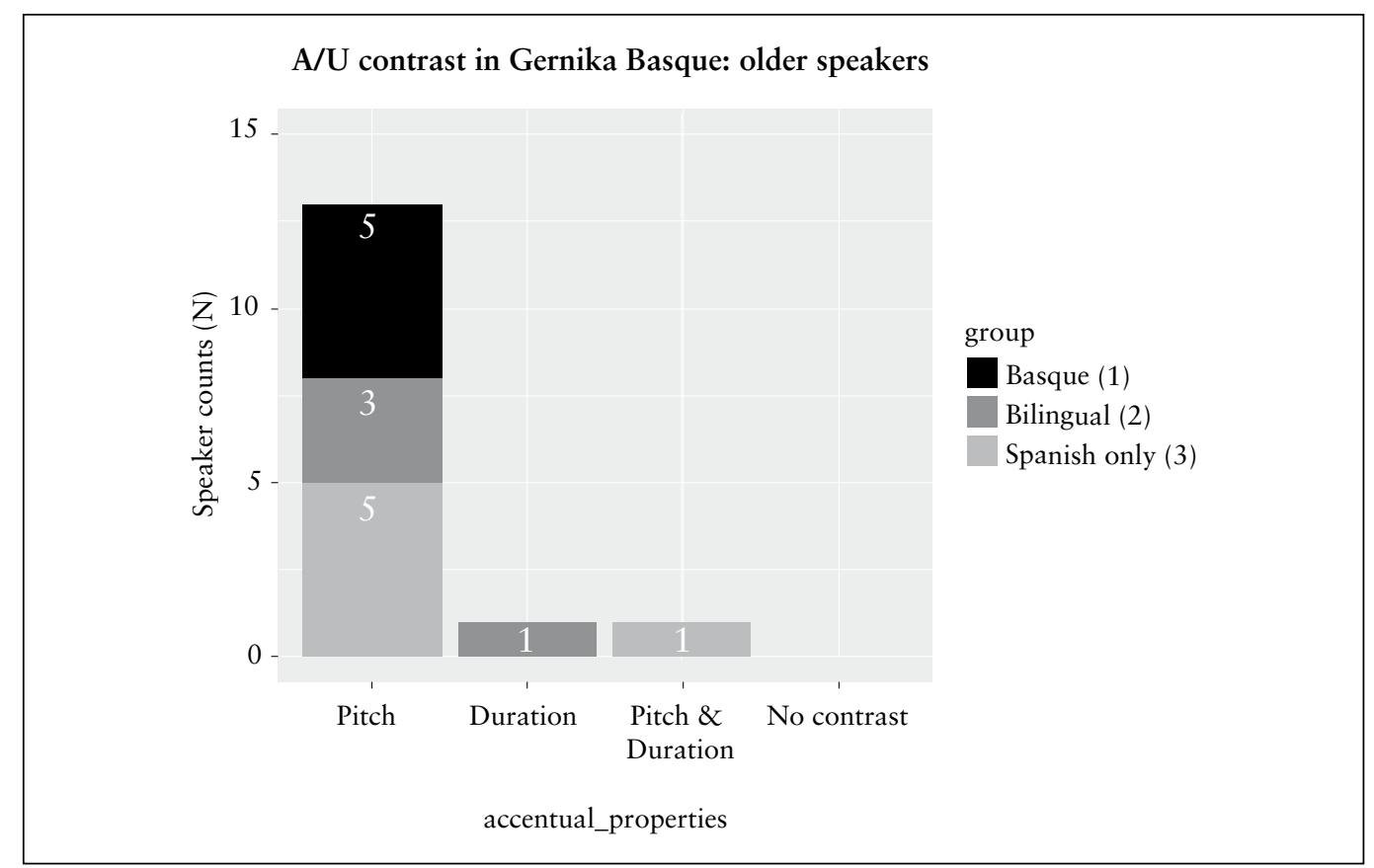

Figure 5. Speaker counts for each category for A/U contrast in older speakers of GB.

Figure 5 shows that out of the 15 older speakers examined here, 13 speakers ( 86.6\%) used only pitch to make a lexical distinction between accented and unaccented words. Only $1(\sim 6.7 \%)$ speaker used both pitch and duration and only $1(\sim 6.7 \%)$ speaker used duration only to produce an accented / unaccented contrast. These results confirm our group analysis in section 4.1 and 4.2 in that older speakers quite robustly maintain a pitch-accent system in Gernika Basque. Figure 6 shows that out of the 30 younger speakers, 12 speakers $(40 \%)$ used only pitch to produce the distinction between lexically accented and unaccented words. 4 speakers (13.3\%) used both pitch and duration, 9 speakers $(30 \%)$ used duration only and 5 speakers $(16.7 \%)$ showed no contrast at all. 


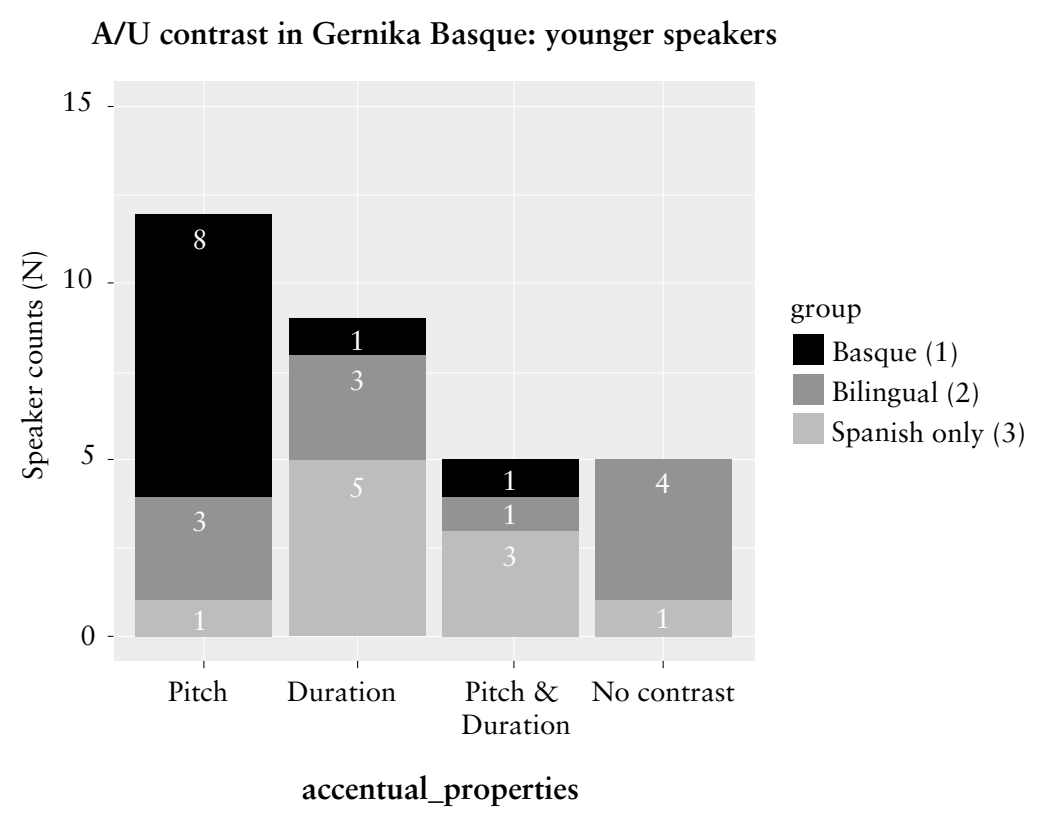

Figure 6. Speaker counts for each category for A/U contrast in younger speakers of GB.

These results confirm that younger speakers exhibit a lot more variation as to how they maintain a distinction between lexically accented and unaccented words. The relationship between pitch and duration is not a straightforward one, however. Among those who do not show a pitch difference between lexically accented and unaccented words $(\mathrm{N}=14)$, only $9(64.3 \%)$ speakers showed an effect of longer durations for accented syllables. Similarly, there were an additional 5 speakers showing a durational correlate effect, but these speakers also show a difference in pitch. As such, we conclude that although duration is not an accentual correlate of Gernika Basque, it may be used by some speakers to convey accentual prominence and such effect is not necessarily contingent on a lack of difference through pitch.

Among those who showed no pitch differences to mark lexically accented and unaccented words, a natural question arises: do speakers produce accented words as unaccented or do they produce unaccented words as accented? The answer to this question is that both patterns are in place. Figures 7 and 8 show the same speaker producing both accented and unaccented words as accented. Notice that the contours for both conditions do not show a downstep effect, but rather are realized with two pitch-accents in the target syllables. 


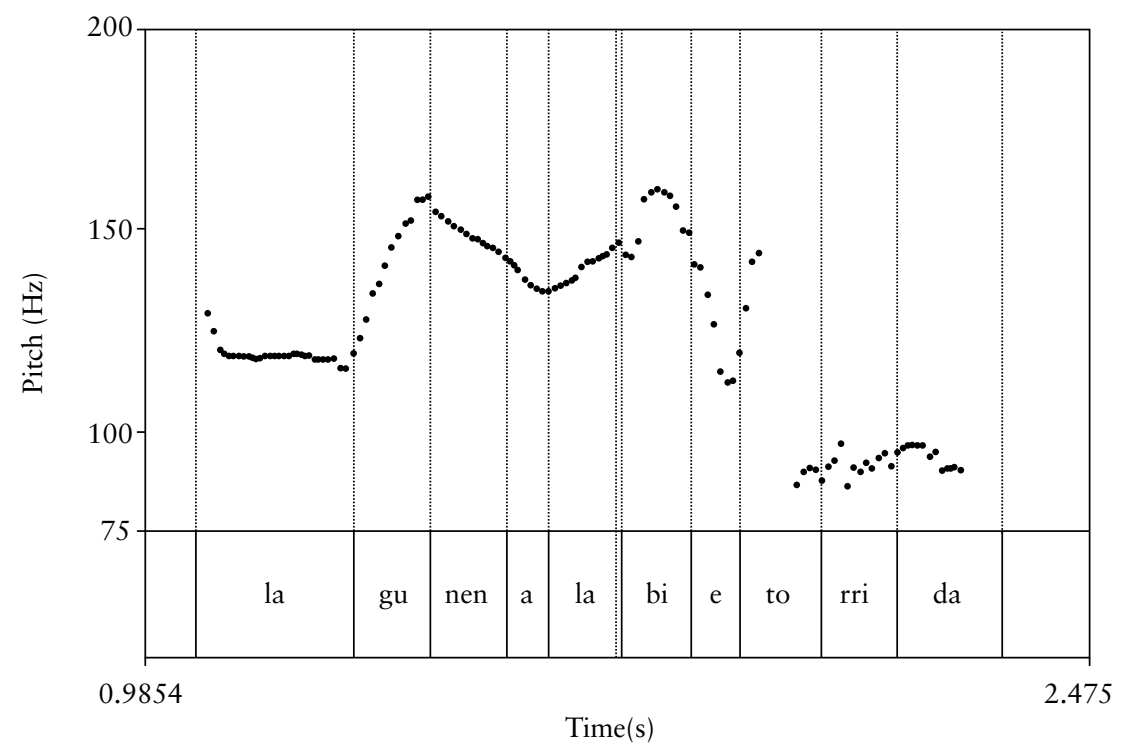

Figure 7. Condition A: lagunen alabiè etorri da 'the friend's daughter has arrived' (sg) (male_35).

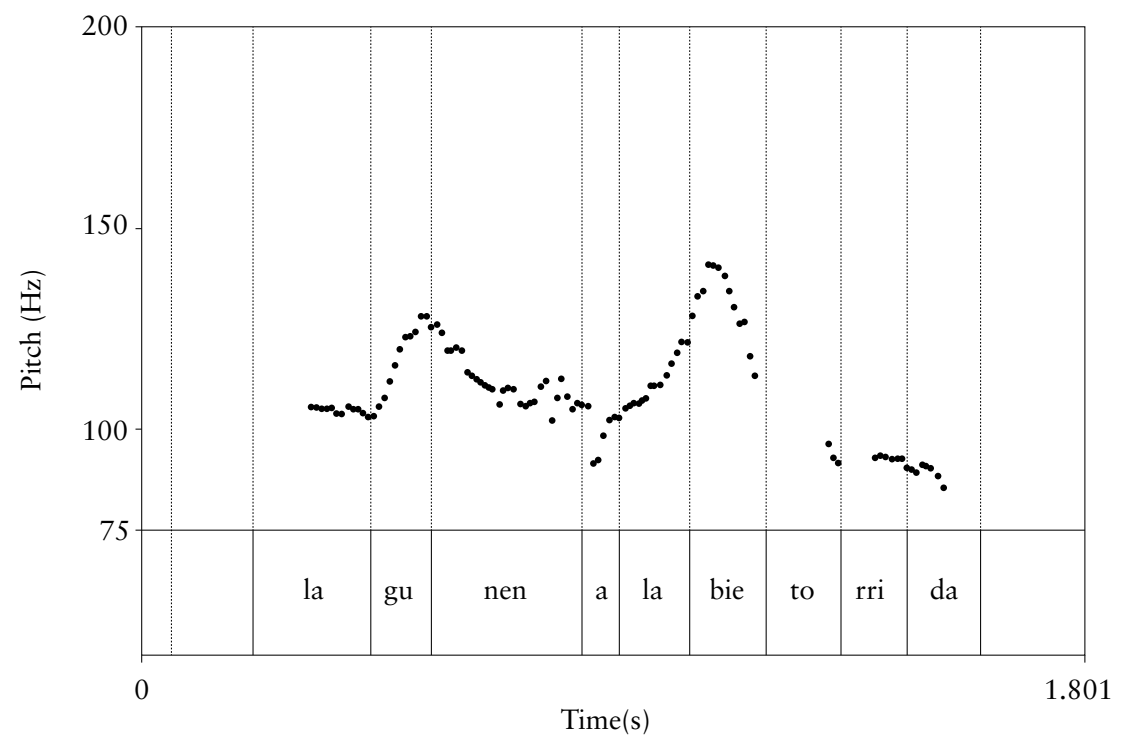

Figure 8. Condition B: lagúnen alabiè etorri da 'the friends' daughter has arrived' (pl) (male_35). 
Figures 9 and 10 show the second pattern in which the same speaker produced both unaccented and accented words as unaccented.

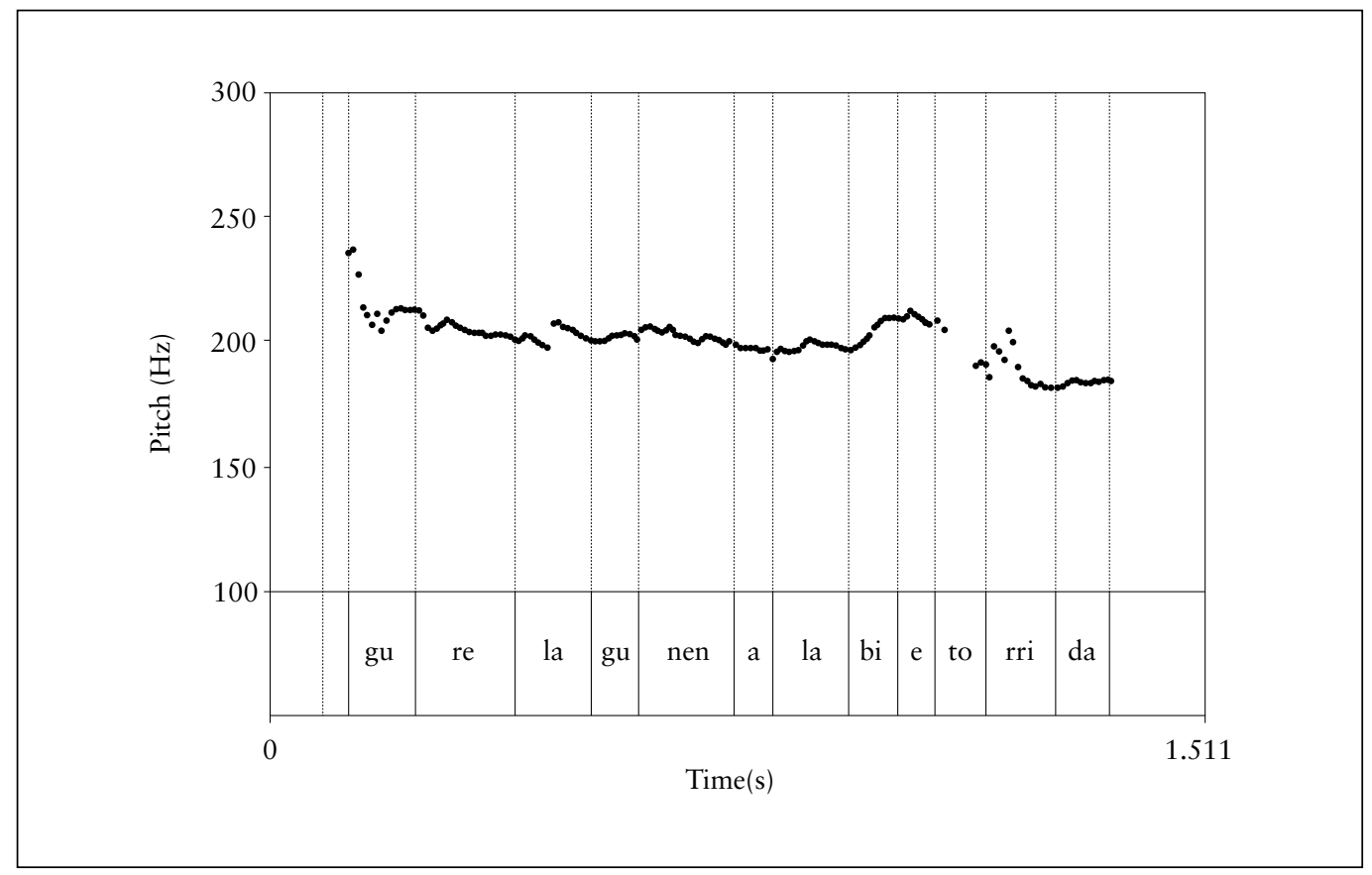

Figure 9. Condition A: lagunen alabiè etorri da 'the friend's daughter has arrived' (sg) (female_18).

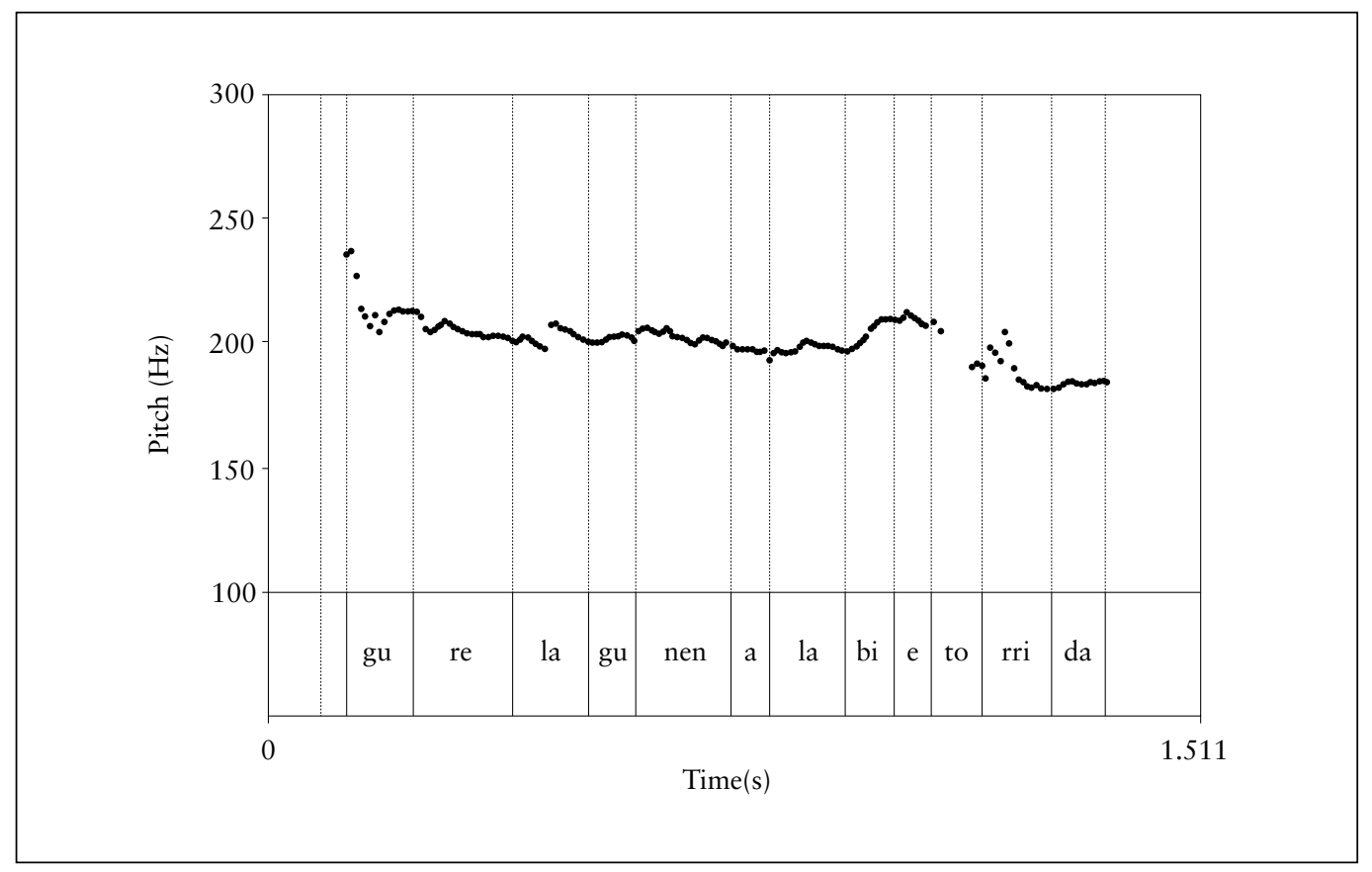

Figure 10. Condition B: lagúnen alabiè etorri da 'the friends' daughter has arrived' (pl) (female_18). 
It is interesting to note that among those speakers who deviate from the norm of maintaining the A/U distinction through pitch only (scenarios 2, 3 and 4) most of them are in groups 2 and 3, namely, they come from either Basque-Spanish households or Spanish only speaking households. These results are congruent with a potentially language contact hypothesis in that speakers that come from either bilingual or Spanish monolingual households are more vulnerable in not distinguishing lexically accented words from accented ones in Gernika Basque. However, no clear pattern was found as to which groups were more likely to use pattern 1 (figures 7 and 8) or pattern 2 (figures 9 and 10). Of the 15 speakers that did not show pitch differences for accented and unaccented words, 9 speakers followed pattern 1 and 6 speakers followed pattern 2. Among those who produced pattern 1, 5 were from Basque-Spanish bilingual households (group 2) and 4 came from Spanish-only speaking households (group 3). Similarly, out of the 6 speakers who followed pattern 2, 3 of them were Basque-Spanish bilingual households and 3 were from Spanish-only speaking households. In terms of social networks, no clear pattern was found, either: among those who produced pattern $1(\mathrm{~N}=9), 6$ belonged to Basque-speaking networks and 3 belonged to Spanish-speaking networks. Among those who produced pattern $2(\mathrm{~N}=6), 5$ belonged to Spanish-speaking networks and 1 to Basque-speaking networks.

\section{DISCUSSION AND CONCLUSIONS}

The main goal of the present study was to examine the extent to which the pitch-accented system of Gernika Basque is adopting a more stress-like pattern. In order to do so, we experimentally tested the production of 8 neutral declarative sentences among 45 Gernika Basque and Spanish bilinguals. Following previous work (Elordieta, 1997, 1998; Jun \& Elordieta, 1997; Hualde et al., 2002, 2002; Elordieta \& Hualde, 2014), we examined two properties of the pitch-accent system of Gernika Basque: 1) the lexical distinction between accented vs. unaccented words in neutral declarative sentences (which is solely conveyed through pitch) and 2) lack of durational correlates of accentual prominence. We tested 3 social factors: age, bilingual group and social networks. It was hypothesized that those who produce a A/U distinction through pitch would not show durational correlates, whereas those that have lost such distinction would show durational correlates of accentual prominence. Our hypotheses were not entirely confirmed.

Results showed that the A/U distinction, measured in terms of downstep, was clearly maintained among older speakers (regardless of bilingual group or social networks). Only 2 older speakers showed an effect of durational correlates of accentual prominence. These results are in accordance with previous work that have examined durational correlates in other varieties of Northern Bizkaian Basque. Elordieta \& Hualde (2001) experimentally tested durational correlates among 6 speakers of Lekeitio Basque in neutral declarative sentences and in narrow focus and post-focus positions. Their results revealed that only one speaker showed significantly longer accented syllables, but such effect was only found in narrow focus position. In a follow-up study, Elordieta $\&$ Hualde (2003) further tested durational correlates in downstep contexts in the same 
variety, to examine whether reduction of pitch differences would lead to increased syllable durations. Their results revealed that among the 5 speakers they examined, only 2 exhibited some tendency to elongate accented syllables under corrective narrow focus. In the absence of speakers' consistency in using duration as an accentual correlate, they concluded that duration does not play a role in the overall realization of the pitch-accent of Lekeitio Basque. Our results from the older speakers further confirm the relevance of pitch (and not duration) in conveying accentual prominence in pitch-accented systems such as Gernika Basque (Beckman, 1986). Results further showed that younger speakers exhibit a lot more variation in their accentual system of Gernika Basque, a variation that was also socially constrained. Although no main effects of social factors such as bilingual group or social networks were found for duration, interesting interactions were found for downstep. Specifically, it was shown that those who come from Spanish-only speaking households (group 3) are also more likely not to show a downstep effect if they also belong to Spanish-speaking networks, a finding that is congruent with a possible language contact effect.

Our second goal was to examine whether speakers who do not to maintain the singular/plural distinction through pitch use duration to convey accentual prominence. The hypothesis was that speakers would show durational correlates if they do not maintain such a distinction. Such hypothesis was not borne out given that accented syllables were not statistically longer than unaccented ones. The individual analyses showed that out of the total 15 speakers that show no pitch differences, only 9 showed a durational correlate. Overall, individual analyses indicate that duration is not a direct correlate of accentual prominence in Gernika Basque but it may be used by some speakers who have lost the $\mathrm{A} / \mathrm{U}$ distinction as a way to convey accentual prominence. A question that we may ask is: what are other cues that speakers use to convey accentual prominence? One such cue could be attributed to intensity. Although intensity has shown not to play such a significant role in Spanish as duration does (Ortega-Llebaria \& Prieto, 2010), it has been found that intensity (and not duration) does play a role in the accentual prominence of Azpeitia Basque (Hualde \& Beristain, 2017). Whether speakers also rely on intensity to convey accentual prominence in Gernika Basque is an endeavor that we leave for future research.

Another question that emerges is why certain young speakers do not show a lexically accented vs. unaccented distinction in pitch. In our individual analysis, it was found that such lack of distinction occurs in two opposite directions: 1) realization of unaccented words as accented and 2) realization of accented words as unaccented. The first pattern could be explained in terms of Hualde's claims on the development of the accentual systems of central Gipuzkoa. According to Hualde (1993, 2003), the intonational rise on the second syllable of unaccented words ( $c f r$. (1a)) may have been interpreted as an accent by bilingual Spanish-Basque speakers, as Spanish accents are rising. This hypothesis was experimentally tested in Elordieta \& Hualde (2006), who examined the perception of word accent in four accentual patterns in Gernika Basque: 1) initial accent (lékuetatik 'from the places'), 2) post-initial accent (eskólara 'to the school'), 3) lexical accent on the third or fourth syllable (Gernikétik 'from Gernika') and 4) final 'derived' accent (alarguneri 'to the widow'). They tested 3 groups of speakers: native 
speakers of Northern Bizkaian Basque, speakers of Southern Bizkaia or central Gipuzkoa and L2 Basque speakers from Gasteiz. Their results showed that Spanish-dominant speakers perceived accentual prominence on the syllable that was associated with a tonal rise instead of the syllables that contained a pitch accent, congruent with the claim that language dominance plays a role as to how Basque speakers may reinterpret tonal rises as accents. In order to see whether the same reinterpretation is occurring among those showing downstep in both conditions $\mathrm{A}$ and $\mathrm{B}$, future work could benefit from a similar perceptual study among speakers who produce unaccented words as accented in Gernika Basque.

In terms of the second pattern, we could propose that, because Spanish does not distinguish between lexically accented and unaccented words, speakers may generalize the (abstract) rule that Gernika Basque lacks such distinction. Another possibility could be linked to the role that social meaning plays in social differentiation. Amidst the recurring linguistic ideologies of using language as a symbolic resource of linguistic differentiation and identity authentication (Urla, 2012; Rodríguez-Ordóñez, 2016), it could be that speakers may reinterpret the possible rule of non-distinction between accented and unaccented words in favor of unaccented ones as a means of differentiating Gernika Basque from Spanish, which does not distinguish between accented and unaccented words in favor of lexically accented ones. That is, pattern 2 could be seen as a case of hyper-correction. Examining the social significance attributed to each of the patterns found in this study could have important implications for our understanding that the role that language attitudes, identities and linguistic ideologies may have in theories of sound change. In previous work, Romera \& Elordieta (2013) examined potential dialect and language contact effects on the Spanish prosody of Majorcan Spanish among 4 monolingual Spanish-speaking arrivals who have been living in Majorca between 2.5 to 8 years. Their results showed that speakers with higher determination to integrate in the new sociolinguistic environment were more likely to adopt more "Majorcan Spanish" intonational features, patterns that were argued to be the result of accommodation, not necessarily contact-induced change.

More recently, Elordieta \& Romera (in press) examined the influence of social factors in absolute interrogatives in the Spanish spoken in contact with Basque. The 12 speakers examined were either monolingual Spanish speakers, L1 Spanish-L2 Basque or L1 Basque-L2 Spanish. In their results, all three groups showed a majority of falling or rising-falling final contours for absolute interrogatives, in contrast to the more common final rising configurations of Castilian Spanish. However, in their examination of the effect of the speakers' overall attitudes towards the Basque language and the degree of contact with Basque, they found that overall positive attitudes towards the Basque language as well as contact with Basque correlated with higher production of final rising-falling contours, whereas those with less positive attitudes towards Basque showed more rising contours as in Standard Spanish. Both factors combined (degree of contact and attitudes towards Basque) were able to account for $74 \%$ of the data. One potential extension of our current study is to examine the attitudes that Gernika Basque speakers show towards each of the patterns and to determine whether those attitudes correlate with their uses. Thus, the effect of attitudes towards Basque or the social significance 
behind each of the overgeneralized patterns found for Gernika Basque prosody in this study is a promising future project that will allow us to better understand the way linguistic ideologies induce potential linguistic changes in contact situations.

\section{REFERENCES}

Beckman, M. E. (1986). Stress and non-stress accent. Dordrecht: Foris.

Beckman, M. E. \& Pierrehumbert, J. B. (1986). Intonational structure in English and Japanese. Phonology, 3(1), 255-309.

Boersma, P. \& Weenink, D. (2018). Praat: doing phonetics by computer [Computer program]. Version 6.0.37.

Chambers, J. K. (2004). Patterns of variation including change. In J. K. Chambers, P. Trudgill \& N. Schilling-Estes (eds.), The handbook of language variation and change (pp. 349-372). Malden: Blackwell.

Elordieta, G. (1997). Accent, tone and intonation in Lekeitio Basque. In F. Martínez \& A. Morales-Font (eds.), Issues in the phonology and morphology of major Iberian languages (pp. 1-78). Washington, D.C: Georgetown University Press.

Elordieta, G. (1998). Intonation in a pitch accent variety of Basque. ASJU, 32(2), 511569.

Elordieta, G. (2003). Intonation. In J. I. Hualde \& J. Ortiz de Urbina (eds.), A Grammar of Basque (pp. 72-112). Berlin / New York: Mouton de Gruyter.

Elordieta, G. (2015). Recursive phonological phrasing in Basque. Phonology, 32(1), 49-78.

Elordieta, G. \& Hualde, J. I. (2001). The role of duration as a correlate of accent in Lekeitio Basque. Proceedings of Eurospeech 2001 Scandinavia (pp. 115-118). Aalborg, Denmark: CPK, Aalborg University.

Elordieta, G. \& Hualde, J. I. (2003). Tonal and durational correlates of accent in contexts of downstep in Lekeitio Basque. Journal of the International Phonetic Association, 33(2), 195-209.

Elordieta, G. \& J. I. Hualde. (2006). Experimental test of a hypothesized diachronic change in Basque accentuation. ASJU, 40, 293-302.

Elordieta, G. \& Hualde, J. I. (2014). Intonation in Basque. In S. Jun (ed.), Prosodic Typology II: The Phonology of Intonation and Phrasing (pp. 407-463). Oxford: Oxford University Press.

Elordieta, G. \& Romera, M. (in press). The influence of social factors on the prosody of Spanish in contact with Basque. In M. Bouzouita, R. Enghels, \& C. Venderschueren (eds.), Different perspectives on convergence and divergence in Ibero-Romance: Language contact and contrastic national varieties. Amsterdam: John Benjamins Publishing Company.

Fant, G. (1970). Acoustic Theory of Speech Production. The Hague: Mouton.

Gaminde, I. (1993). Bermeoko azentu ereduaz. Uztaro, 8, 105-117.

Gaminde, I. (1998). Euskaldunen azentuak. Bilbo: Labayru Ikastegia.

Hualde, J. I. (1988). A theory of pitch-accent, with particular attention to Basque. ASJU, 22(3), 915-919. 
Hualde, J. I. (1991). Basque Phonology. London/New York: Routledge.

Hualde, J. I. (1993). On the historical origin of Basque accentuation. Diachronica, 10, $13-50$.

Hualde, J. I. (1997). Euskararen Azentuerak. Donostia \& Bilbao: Gipuzkoako Foru Aldundia \& Euskal Herriko Unibertsitatea. (Supplements of ASJU, 42).

Hualde, J. I. (2002). Basque accentuation and dialectology. In J. V. Marle J. \& Berns (eds.), Present-day dialectology: Problems and findings (pp. 207-230). Berlin: Mouton de Gruyter.

Hualde, J. I. (2003). From phrase-final to post-initial accent in Western Basque. In P. Fikkert \& H. Jacobs (eds.), Development in prosodic systems (pp. 249281). Berlin: Mouton de Gruyter.

Hualde, J. I. (2005). The Sounds of Spanish. Cambridge: Cambridge University Press.

Hualde, J. I. (2006). Estado actual en las investigaciones sobre la acentuación en lengua vasca. Oihenart, 21, 149-177.

Hualde, J. I., Smiljani , R. \& Cole, J. (2000). On the accented/unaccented distinction in Western Basque and the typology of accentual systems. Proceedings of Berkeley Linguistic Society, 26, 133-144.

Hualde, J. I., Elordieta, G., Gaminde, I. \& Smiljani, R. (2002). From pitch-accent to stress-accent in Basque. In C. Gussenhoven \& N. Warner (eds.), Laboratory Phonology VII (pp. 547-584). Berlin: Mouton de Gruyter.

Hualde, J. I. \& A. Beristain (2017). Azpeitiko azentuaren gauzatze fonetikoaz. Fontes Linguae Vasconum, 123, 65-85.

Ito, J. \& Mester, A. (2013). Prosodic subcategories in Japanese. Lingua, 124, 20-40.

Irurtzun, A. (2003). Stress on Accent: Errenteria Basque Revisited. In M. J. Solé, D. Recasens \& J. Romero (eds.), Proceedings of 15th ICPhS (pp. 2075-2078). Barcelona: Causal Productions.

Jun, S. A. \& Elordieta, G. (1997). Intonational Structure of Lekeitio Basque. In A. Botinis, G. Kouroupetroglou \& G. Carayiannis (eds.), Intonation: Theory, Models and Applications. Proceedings of an ESCA Workshop (pp. 193196). Athens, Greece: ESCA.

Kahane. J. (1978). A morphological study of the human prepubertal and pubertal larynx. American Journal of Anatomy, 151, 11-20.

Kubozono, H. (1993). The organization of Japanese prosody. Tokyo: Kurosio.

Navarro-Tomás, T. (1914). Manual de pronunciación española (3rd ed.). Madrid: Editorial Hernando S. A.

Navarro-Tomás, T. (1964). La medida de la intensidad. Boletín del Instituto de Filología de la Universidad de Chile, 16, 231-235.

Ortega-Llebaria, M. (2006). Phonetic cues to stress and accent in Spanish. In M. Díaz-Campos (ed.), Selected Proceedings of the 2nd conference of Laboratory Approaches to Spanish Phonology (pp. 104-118). Somerville, MA: Cascadilla Press.

Ortega-Llebaria, M. \& Prieto, P. (2010). Acoustic correlates of stress in Central Catalan and Castilian Spanish. Language and Speech, 54(1), 73-97.

Pierrehumbert, J. \& Beckman, M. (1988). Japanese tone structure. Cambridge, Massachusetts: MIT. 
Quilis, A. (1971). Caracterización fonética del acento español. Travaux de Linguistique et de Littérature, 9, 53-72.

Quilis, A. (1981). Fonética acústica de la lengua española. Biblioteca Románica Hispánica. Madrid: Gredos.

R Core Team (2016). R: A language and environment for statistical computing. R Foundation for Statistical Computing, Vienna, Austria. Available online: < https://www.R-project.org> , <http://www.rstudio.com>.

Rodríguez-Ordóñez, I. (2016). Differential Object Marking in Basque: grammaticalization, attitudes and ideological representations. Unpublished Ph.D. Dissertation, University of Illinois at Urbana-Champaign.

Rodríguez-Ordóñez, I. \& Gillig, K. (2018). Effects of language contact in pitch-accents: The case of Gernika Basque. Proceedings from the Annual Meeting of the Chicago Linguistic Society, 52, 405-419.

Romera, M. \& Elordieta, G. (2013). Prosodic accommodation in language contact: Spanish intonation in Majorca. International Journal of the Sociology of Language, 221, 127-151.

Urla, J. (2012). Reclaiming Basque: Language Nation and Cultural Activism. Reno: University of Nevada.

\section{APPENDIX}

Appendix I: Individual results

\begin{tabular}{|c|c|c|c|}
\hline \multirow{2}{*}{$\begin{array}{l}\text { Older } \\
\text { speakers } \\
\text { GROUP }\end{array}$} & \multicolumn{2}{|c|}{$\begin{array}{c}\text { F0 }(\mathrm{Hz}) \\
\text { Differences }\end{array}$} & \multirow{2}{*}{$\begin{array}{l}\text { Duration Differences } \\
\text { in milliseconds } \\
\text { gu - gú } \\
\text { (accented - accented) }\end{array}$} \\
\hline & $\begin{array}{c}\mathrm{W}_{1}-\mathrm{W}_{2} \\
\text { Condition } \mathrm{A}(\mathrm{U} / \mathrm{A})\end{array}$ & $\begin{array}{c}\mathrm{W}_{1}-\mathrm{W}_{2} \\
\text { Condition B (A/A) }\end{array}$ & \\
\hline$\# 7$ f $(3)$ & $-3,78$ & 46,75 & 3 \\
\hline$\# 9$ _f $(2)$ & 6,63 & 19,03 & 1,4 \\
\hline$\# 10 \_f(1)$ & 1,73 & 31,35 & $-10,8$ \\
\hline$\# 11 \_f(3)$ & $-4,2$ & 27,31 & 1,8 \\
\hline$\# 12 \_f(3)$ & 2,78 & 39,85 & $-20,4$ \\
\hline$\# 19 \_f(3)$ & 2,48 & 38,22 & $-1,6$ \\
\hline$\# 20 \_f(2)$ & $-6,67$ & 25,13 & $-10,5$ \\
\hline$\# 21 \_f(2)$ & 9,93 & 17,3 & -11 \\
\hline$\# 22 \_f(1)$ & $-13,13$ & 55,2 & $-6,3$ \\
\hline$\# 23 \_f(3)$ & 0,63 & 21,27 & $-10,2$ \\
\hline$\# 37 \_f(1)$ & 1,56 & 42,18 & 11 \\
\hline$\# 67 \_f(3)$ & 1,7 & 52,38 & $-2,6$ \\
\hline$\# 68 \_f(2)$ & $-0,5$ & 21,45 & 7,2 \\
\hline$\# 70 \_\mathrm{f}(1)$ & 4,73 & 33 & 7,8 \\
\hline$\# 72$ f $(1)$ & $-7,6$ & 42,33 & $-6,2$ \\
\hline
\end{tabular}




\begin{tabular}{|c|c|c|c|}
\hline \multirow[t]{2}{*}{$\begin{array}{l}\text { Younger } \\
\text { speakers }\end{array}$} & \multicolumn{2}{|c|}{$\begin{array}{c}\text { F0 }(\mathrm{Hz}) \\
\text { Differences }\end{array}$} & \multirow{2}{*}{$\begin{array}{l}\text { Duration Differences } \\
\text { in milliseconds } \\
\text { gu - gú }\end{array}$} \\
\hline & $\begin{array}{c}\mathrm{W}_{1}-\mathrm{W}_{2} \\
\text { Condition } \mathrm{A} \text { (U/A) }\end{array}$ & $\begin{array}{c}\mathrm{W}_{1}-\mathrm{W}_{2} \\
\text { Condition } \mathrm{B}(\mathrm{A} / \mathrm{A})\end{array}$ & \\
\hline \#4_f (1) & $-9,97$ & 49,37 & 7,4 \\
\hline$\# 5 \_f(1)$ & $-2,58$ & 27,58 & 3,8 \\
\hline$\# 6 \_f(1)$ & $-9,2$ & 35,05 & $-1,2$ \\
\hline$\# 7$ f $(2)$ & $-8,23$ & 45,23 & $-25,5$ \\
\hline \#8_m (2) & 1,13 & 10,28 & $-6,3$ \\
\hline \#9_m (2) & $-1,28$ & 10,35 & 12,1 \\
\hline$\# 13 \_f(2)$ & 8,65 & 17,15 & 15,1 \\
\hline \#14_m (2) & 0,43 & 15,67 & $-3,1$ \\
\hline \#15_m (2) & $-1,9$ & 15,05 & 7,4 \\
\hline$\# 16 \_f(2)$ & $-4,13$ & 38,5 & $-4,6$ \\
\hline$\# 17 \_f(3)$ & $-7,28$ & 17,93 & $-8,1$ \\
\hline$\# 18$ (1) & $-0,9$ & 42,2 & $-4,2$ \\
\hline$\# 25 \_f(2)$ & $-7,13$ & 12,4 & $-55,1$ \\
\hline$\# 27$ m (3) & $-4,7$ & $-0,43$ & $-14,6$ \\
\hline$\# 30 \_f(3)$ & $-5,23$ & 13,1 & -14 \\
\hline$\# 41 \_f(3)$ & $-4,75$ & 30,2 & $-35,2$ \\
\hline \#44_m (2) & 1,75 & 4,05 & 9,6 \\
\hline$\# 47 \_f(1)$ & $-7,88$ & 22,36 & $-8,6$ \\
\hline \#49_f (1) & $-4,1$ & 25,55 & $-7,4$ \\
\hline$\# 50 \_f(1)$ & $-5,8$ & 28,6 & $-11,5$ \\
\hline$\# 51 \_\mathrm{m}(2)$ & $-0,3$ & 8,93 & $-35,4$ \\
\hline$\# 53 \_f(3)$ & 1,98 & 12,88 & $-8,2$ \\
\hline$\# 54 \_f(3)$ & 10,2 & 40,43 & $-20,2$ \\
\hline \#59_m (1) & $-4,13$ & 23,98 & $-2,4$ \\
\hline \#60_m (2) & 4 & 10,61 & -18 \\
\hline \#61_m (3) & $-0,55$ & 17,28 & $-15,4$ \\
\hline \#63_m (3) & 3,28 & 1,8 & $-13,4$ \\
\hline$\# 75 \_f(3)$ & $-1,25$ & $-2,82$ & $-42,4$ \\
\hline$\# 76 \_f(1)$ & 10,28 & 11,66 & -17 \\
\hline$\# 77 \_f(1)$ & 8,43 & 33,07 & $-40,3$ \\
\hline
\end{tabular}




\section{Appendix II: Full list of experimental materials}

1. Lagunen alabiè etorri $\mathrm{da}$

2. Lagúnen alabiè etorri da

3. Fidelen alabiè etorri da

4. Fidélan alabiè etorri da

5. Lagunen amúma ikusi dot

6. Lagúnen amúma ikusi dot

7. Abadien libúrue ikusi dot

8. Abadíen libúrue ikusi dot 
0000 